Заседа Ю.И.

ОЦЕНКА ЭФФЕКТИВНОСТИ ПРИМЕНЕНИЯ

БРУСНИЧНОЙ

И ЧЕРНИЧНОЙ ПАСТ В КОМПЛЕКСНОМ ЛЕЧЕНИИ ХРОНИЧЕСКОГО БАКТЕРИАЛЬНОГО ПРОСТАТИТА

Клиника «Мужское Здоровье» г. Киев, Украина

\title{
Zasieda Yu.l. \\ ASSESSMENT OF THE EFFICIENCY OF THE APPLICATION OF THE COWBERRY AND BLUEBARRY PASTE IN COMPLEX TREATMENT OF CHRONIC BACTERIAL PROSTATITIS
}

\section{Men's Health Clinic, Kyiv, Ukraine}

Резюме С иелью оченки эффрективности применения брусничной и черничной паст в комплексном лечении хронического бактериального простатита было обследовано 72 пациента клиники «Мужское здоровье», г.Киев. По результатам обследования были сформированы 2 симметричные группы по 23 пациента. Основная группа проходила лечение по модели: антибиотикотерапия, вспомогательная фармакотерапия (венотонические препараты и ферменты), локальная физиотерапия и диетотерапия с включением в диету брусничной и черничной паст. Группа контроля получала аналогичное лечение, но без изменения диеты.

Оченка эффрективности применения брусничной и черничной паст в комплексном лечении хронического бактериального простатита показывает, что пациенты, проходившие терапию с включением в рацион питания гомогенизированных брусничной и черничной паст - демонстрируют меньшую интенсивность симптомов хронического бактериального простатита (по данным шкалы I-PSS) через 3 месяца после окончания лечения, а именно: «ургентности мочеиспускания» и «субъективного снижения качества жизни» $(p=0,03)$.

Ключевые слова: простатит, диетотерапия, брусничная паста, черничная пасma.

Актуальность. Хронические воспалительные заболевания предстательной железы являются центральной проблемой андро-урологической клиники. Особенности клинических проявлений воспалительных заболеваний предстательной железы в значительной степени снижают качество жизни больного, оказывая выраженное негативное влияние на функциональное состояние мочеполовой системы и копулятивной функции, обладая также комплексом симптомов, вызывающих болевые ощущения и выраженный дискомфорт. Данный класс патологии имеет высокую популяционную распространенность при низкой эффективности рутинных терапевтических процедур в отношении эрадикации возбудителя, что создаёт тенденцию к её эпидемиологической кумуляции $[1,3,5]$.

Основными факторами, снижающими неспецифическую сопротивляемость организма к микробной флоре, являются нарушения локальной гемодинамики и состояния сосудистой стенки, что отражается не только на вероятности развития заболевания, но и на качестве и продолжительности ремиссий при хроническом бактериальном простатите [2,4].

В настоящее время можно выделить ряд факторов, которые оказывают значительное влияние на указанные показатели. Снижение локальной гемодинамики, а 
именно венозный застой в области органов малого таза, который обусловлен специфической гиподинамией, присущей урбанистическому образу жизни, а именно длительными периодами сохранения сидячего положения. Нарушения состояния сосудистой стенки определяются наличием естественного оксидантного стресса, повреждающих и дестабилизирующих факторов при сниженном уровне защитных факторов, прежде всего антиоксидантов и веществ, участвующих в метаболизме компонентов соединительной ткани $[2,4,6]$.

В настоящее время наряду с развитием фармакотерапевтических средств лечения хронического бактериального простатита, значительное внимание уделяется вспомогательным методам, направленным на создание условий для снижения уровня локальных сосудистых и гемодинамических нарушений, а именно: биологическим, физиотерапевтическим методам и диетотерапии, направленным на стимуляцию естественного восстановления сосудистой стенки. К методу диетотерапии относится введение в диету естественных источников флавонидов, органических кислот, витаминов, полиненасыщенных жирных кислот, оказывающих антиоксидантный эффект и являющихся биологически активными по отношению к процессу структурного восстановления сосудистой стенки и регуляции её тонуса, а именно: гомогенизированных плодов брусники и черники в виде паст $[2,6]$.

Оценка эффективности терапии хронического бактериального простатита с использованием диетотерапии в качестве вспомогательного метода, является важным аспектом развития комплексного подхода к лечению данной патологии.

Цель исследования: оценка эффективности применения брусничной и черничной паст в комплексном лечении хронического бактериального простатита.

Материалы и методы: исследование проведено в проспективном дизайне на параллельных группах. Контингент исследования составили 72 пациента ООО «Клиника «Мужское Здоровье», обративших- ся для амбулаторного лечения по поводу хронического бактериального простатита, из которых было выделено 56 пациентов с простатитом, вызванным неспецифической микробной флорой. Контингент сформирован методом сплошной выборки. В исследовании использованы следующие методы:

- клинический: стандартный комплекс клинических обследований, клиническая шкала I-PSS (International Prostate Symptom Score), для оценки выраженности симптомов хронического бактериального воспаления предстательной железы;

- сонографическое исследование предстательной железы (ТРУЗИ): с целью оценки степени и характера поражения;

- бактериальный посев эякулята на наличие патогенной микрофлоры, с определением антибиотикочувствительности;

- ПЦР диагностика основных возбудителей венерологических заболеваний.

\section{Результаты исследования}

Инициальное обследование контингента исследования дало следующие результаты:

- бактериальный посев эякулята и ПЦР диагностика основных возбудителей венерологических заболеваний указало, что воспалительный процесс обусловлен исключительно неспецифической микробной флорой в 56 случаях; у 16 пациентов были обнаружены различные варианты микст-инфекций (сочетания условно-патогенной бактериальной флоры с грибковой инфекцией, внутриклеточными возбудителями либо вирусной инфекцией), на основании чего они были исключены из исследования. Анализ антибиотикочувствительности неспецифической микробной флоры позволил установить возможность использования левофлоксацина либо доксициклина во всех 56 случаях;

- трансуретральное сонографическое исследование предстательной железы 
позволило установить гомогенность контингента по критерию объективной тяжести поражения предстательной железы, а также отсутствие дополнительной патологии (объемных образований, конкрементов и проч.);

- клиническая шкала I-PSS позволила установить уровень тяжести клинических проявлений воспалительного процесса предстательной железы до начала лечения (табл. 1). Анализ результатов позволил установить ка- чественные значения по каждому из показателей доступных для анализа в I-PSS. Для этого значения 1-2 балла для показателя были расценены как легкие (субклинические) проявления, 3-5 баллов - как тяжелые (клинические). В дальнейшем, критерием клинической эффективности терапии стал факт перехода показателей I-PSS из категории «клинических» (К) в категорию «субклинических» (СK) проявлений.

\section{Таблица 1}

Показатель клинической тяжести хронического бактериального воспаления предстательной железы до начала терапии (по данным клинической шкалы I-PSS)

\begin{tabular}{|l|c|c|}
\hline \multirow{2}{*}{\multicolumn{1}{|c|}{ Показатель }} & K & CK \\
\cline { 2 - 3 } & \multicolumn{2}{|c|}{ Абс. (n) } \\
\hline Чувство неполного опорожнение мочевого пузыря & 43 & 13 \\
\hline Учащенное мочеиспускание & 49 & 7 \\
\hline Прерывистое мочеиспускание & 32 & 24 \\
\hline Ургентность мочеиспускания & 22 & 34 \\
\hline Ослабление струи мочи & 46 & 38 \\
\hline Затруднение мочеиспускания & 18 & 0 \\
\hline Субъективное снижение качества жизни & 56 & \\
\hline
\end{tabular}

По результатам клинического обследования были сформированы симметричные группы исследования.

1. Основная групnа (ОГ): 23 пациента, которые прошли лечение по модели:

- антибиотикотерапия в зависимости от антибиотикочувствительности обнаруженной микрофлоры, использовалась одна из следующих схем: левофлоксацин - 500 мг орально 1 раз в сутки на протяжении 14-28 суток, либо доксициклин - первый приём 200 мг, далее по 100 мг орально 2 раза в сутки на протяжении 14-28 суток.

- вспомогательная фармакотерапия (венотонические препараты на основе биофлавоноидов; ферментные препараты - вобензим), ежедневно на протяжении 15 суток в стандартных дозировках для данного вида патологии;

- локальная физиотерапия (аппаратный пневмовибромассаж предстательной железы - ежедневно, и трансректальная ультразвуковая терапия предстательной железы ежедневно на протяжении 15 суток (всего 15 сочетанных процедур);

- диетотерапия (включение в рацион питания гомогенизированных брусничной и черничной паст - из расчёта 1 гр на килограмм в сутки каждой, разделённой на 3 приёма, после приема пищи в течение 3-х месяцев от начала лечения).

2. Группа контроля (ГК): 23 пациента, которые прошли лечение по аналогичной терапевтической модели, но без внесения диетотерапевтических рекомендаций.

После окончания 15-дневного курса терапии было проведено повторное исследование контингента, направленное на установление клинической эффективности и сравнения использованных терапевтических моделей (табл. 2). 
Сравнительная эффективность исследуемых терапевтических моделей (по данным клинической шкалы I-PSS) после окончания курса терапии

\begin{tabular}{|l|c|c|c|c|c|}
\hline \multirow{2}{*}{} & \multicolumn{2}{|c|}{$\begin{array}{c}\text { ОГ } \\
\text { Показатель }\end{array}$} & \multirow{2}{*}{$\mathbf{p}\left(\mathbf{\chi}^{2}\right)$} & \multicolumn{2}{c|}{$\begin{array}{c}\text { 厂K } \\
\text { (n=23) }\end{array}$} \\
\cline { 2 - 3 } \cline { 6 - 7 } & $\mathbf{K}$ & $\mathbf{C K}$ & & $\mathbf{K}$ & $\mathbf{C K}$ \\
\hline Чувство неполного опорожнение мочевого пузыря & 1 & 22 & 0,55 & 2 & 21 \\
\hline Учащенное мочеиспускание & 2 & 21 & 1,00 & 2 & 21 \\
\hline Прерывистое мочеиспускание & 0 & 23 & - & 0 & 23 \\
\hline Ургентность мочеиспускания & 0 & 23 & - & 0 & 23 \\
\hline Ослабление струи мочи & 4 & 19 & 0,38 & 2 & 21 \\
\hline Затруднение мочеиспускания & 0 & 23 & - & 0 & 23 \\
\hline Субъективное снижение качества жизни & 2 & 21 & 0,63 & 3 & 20 \\
\hline
\end{tabular}

Клиническая эффективность обеих терапевтических моделей после окончания 15-дневного курса терапии не отличалась и находилась на высоком уровне (85-100\% случаев обнаружили переход из категории «клинических» (К) в категорию «субклинических» (СК) проявлений). При этом эффективность моделей не отличалась между собой.
В качестве катамнестического исследования через 3 месяца было проведено повторное обследование контингента, направленное на установление клинической эффективности и сравнения использованных треапевтических моделей в отдаленном периоде (табл. 3).

Таблица 3

Сравнительная эффрективность исследуемых терапевтических моделей (по данным клинической шкалы I-PSS) через 3 месяца после окончания курса терапии

\begin{tabular}{|c|c|c|c|c|c|}
\hline \multirow[t]{2}{*}{ Показатель } & \multicolumn{2}{|c|}{$\underset{(n=23)}{\text { OГ }}$} & \multirow[t]{2}{*}{$\mathrm{p}\left(\chi^{2}\right)$} & \multicolumn{2}{|c|}{  } \\
\hline & K & СК & & K & CK \\
\hline Чувство неполного опорожнение мочевого пузыря & 2 & 21 & 0,11 & 6 & 17 \\
\hline Учащенное мочеиспускание & 2 & 21 & 0,21 & 5 & 18 \\
\hline Прерывистое мочеиспускание & 0 & 23 & - & 0 & 23 \\
\hline Ургентность мочеиспускания & 0 & 23 & 0,03 & 4 & 19 \\
\hline Ослабление струи мочи & 4 & 19 & 0,29 & 7 & 16 \\
\hline Затруднение мочеиспускания & 0 & 23 & 0,31 & 1 & 22 \\
\hline Субъективное снижение качества жизни & 6 & 17 & 0,03 & 13 & 10 \\
\hline
\end{tabular}

Анализ результатов позволил установить, что в ГК отмечается достоверно больший уровень клинических проявлений по показателям "ургентность мочеиспускания» и «субъективное снижение качества жизни» ( $\mathrm{p}=0,03)$. При этом иные показатели, такие как «чувство неполного опорожнение мочевого пузыря», «учащенное мочеиспускание» и «ослабление струи мочи» - также демонстрируют тенденцию к большей клинической тяжести в ГК, хотя и не достигают при этом достоверного уровня различий в группах.

Выводы: оценка эффективности применения брусничной и черничной паст в комплексном лечении хронического бактериального простатита показывает, что паци- 
енты, проходившие терапию с включением В рацион питания гомогенизированных брусничной и черничной паст, демонстрируют меньшую интенсивность симптомов хронического бактериального простатита (по данным шкалы I-PSS) через 3 месяца после окончания лечения, а именно: «ургентности мочеиспускания» и «субъективного снижения качества жизни» $(p=0,03)$.

Указанные результаты говорят о влиянии диетотерапии с включением в рацион гомогенизированных брусничной и черничной паст на отсроченные результаты лечения, а именно на уровень ремиссии и частоту возвращения симптомов хронического бактериального простатита. Данный результат может быть объяснен включением в метаболизм пациентов биологически активных веществ естественного происхождения: органических кислот, полиненасыщенных жирных кислот Омега-3, Омега-6, витаминов С, B, E, каротиноидов, фитофлавонидов естественного происхождения, в результате чего посредством снижения уровня нарушений функционирования сосудистой стенки, антиоксидантного эффекта в отношении факторов микробной агрессии и стимуляции неспецифического иммунного ответа, происходит повышение общей сопротивляемости организма к бактериальной инфекции, что отражается на более высоком качестве ремиссии.

\section{СПИСОК ИСТОЧНИКОВ ЛИТЕРАТУРЫ}

1. Горпинченко І.І., Литвинець Є.А., Сандурський 0.П. та ін. Діагностика хронічного простатиту: сучасні реалії та проблеми // Здоровье мужчины. 2014. № 1. С. 105-110.

2. Gallo L. Effectiveness of diet, sexual habits and lifestyle modifications on treatment of chronic pelvic pain syndrome. Prostate Cancer Prostatic Dis 2014; 17: 238-245.

3. Giubilei G., Mondaini N., Minervini A., Saieva C., Lapini A., Serni S. et al. Physical activity of men with chronic prostatitis/chronic pelvic pain syndrome not satisfied with conventional treatments — could it represent a valid option? The physical activity and male pelvic pain trial: a double-blind, randomized study. J Urol 2007; 177: 159-165.

4. Herati AS, Shorter B, Srinivasan AK, Tai J, Seideman C, Lesser M et al. Effects of foods and beverages on the symptoms of chronic prostatitis/chronic pelvic pain syndrome. Urology 2013; 82: 1376-1380.

5. Nickel JC, Downey J, Hunter D, Clark J. Prevalence of prostatitis-like symptoms in a population based study using the National Institutes of Health chronic prostatitis symptom index. J Urol 2001; 165: 842-845.

6. Tripp DA, Nickel JC, Shoskes D, Koljuskov A. A 2-year follow-up of quality of life, pain, and psychosocial factors in patients with chronic prostatitis/chronic pelvic pain syndrome and their spouses. World J Urol 2013; 31: 733-739.

\section{PEЗЮME}

\section{ОЦІНКА ЕФЕКТИВНОСТІ ЗАСТОСУВАННЯ БРУСНИЧНОЇ І ЧОРНИЧНОЇ ПАСТ В КОМПЛЕКСНОМУ ЛІКУВАННІ ХРОНІЧНОГО БАКТЕРІАЛЬНОГО ПРОСТАТИТУ}

Засєда Ю.І.

Клініка «Чоловіче Здоров'я» м Київ, Україна

3 метою оцінки ефективності застосування брусничної і чорничної паст в комплексному лікуванні хронічного бактеріального простатиту було обстежено 72 пацієнти клініки «Мужское здоровье», м.Київ. За результатами обстеження були сформовані 2 симетричні групи по 23 пачієнта. Основна група проходи- ла лікування за моделлю: антибіотикотерапія, допоміжна фрармакотерапія (венотонічні препарати і ферменти), локальна фізіотерапія та дієтотерапія з включенням в дієту брусничної і чорничної nacm. Група контролю отримувала аналогічне лікування, але без зміни дієти.

Очінка есрективності застосування брусничної і чорничної паст в комплексному лікуванні хронічного бактеріального простатиту показує, що пацієнти, які проходили терапію з включенням в рачіон харчування гомогенізованих брусничної і чорничної паст, демонструють меншу інтенсивність симптомів хронічного бактеріального простатиту (за даними шкали I-PSS) через 3 місяці після за- 
кінчення лікування, а саме: «ургентності сечовипускання» та «сублєктивного зниження якості життя» $(p=0,03)$.

Ключові слова: простатит, diєmoтерапія, бруснична паста, чорнична паста.

\section{SUMMARY}

ASSESSMENT OF THE EFFICIENCY OF THE APPLICATION OF THE COWBERRY AND

BLUEBARRY PASTE IN COMPLEX TREATMENT OF CHRONIC BACTERIAL PROSTATITIS

\author{
Zasieda Yu.I. \\ Men's Health Clinic, Kyiv, Ukraine
}

In order to evaluate the effectiveness of cowberry and blueberry pastes in the complex treatment of chronic bacterial prostatitis, 72 patients of the Men's Health clinic in Kyiv were examined. Ac- cording to the survey results, 2 symmetric groups of 23 patients were formed. The main group was treated according to the model: antibiotic thera$p y$, auxiliary pharmacotherapy (venotonic drugs and enzymes), local physiotherapy and diet therapy with the inclusion of cowberry and blueberry pastes. The control group received a similar treatment, but without changing the diet.

Evaluating the effectiveness of cowberry and blueberry pastes in the complex treatment of chronic bacterial prostatitis shows that patients treated with the inclusion of homogenized cowberry and blueberry pastes in the diet demonstrate a lower intensity of symptoms of chronic bacterial prostatitis (according to the I-PSS scale) 3 months after treatment, namely: "urination urgency" and "subjective reduction in the quality of life" ( $p=0.03$ ).

Key words: prostatitis, diet therapy, cowberry paste, blueberry paste.

\section{АВТОРСКАЯ СПРАВКА}

- Заседа Юрий Игоревич, д. м. н. Главный врач клиники «Мужское Здоровье» г. Киев. Телефон: +380976500444. E-mail: zasieda@gmail.com.

- Засєда Юрій Ігорович, д. м. н. Головний лікар клініки «Мужское Здоровье» м. Київ. Телефон: +380976500444. E-mail:zasieda@gmail.com.

- Zasieda Yuri Igorevich. MD, Urologyst, Andrologyst, PhD, Doctor of Science, CMO of Men's Health Clinic, Kyiv. Contact number: +380976500444. E-mail:zasieda@gmail.com. 